\title{
The influence of temperature and humidity on abundance and richness of Calliphoridae (Diptera)
}

\author{
Rodrigo R. Azevedo \& Rodrigo F. Krüger \\ 1. Universidade Federal de Pelotas, Instituto de Biologia, Laboratório de Ecologia de Parasitos e Vetores, Campus Universitário s/n, caixa postal 354, 96010-000, Pelotas, RS, Brasil. \\ (rodrigorickes@hotmail.com; rfkruger@gmail.com)
}

\begin{abstract}
The blowfly species are important components in necrophagous communities of the Neotropics. Besides being involved in the degradation of animal organic matter, they may serve as vectors for pathogens and parasites, and also cause primary and secondary myiasis. The occurrence pattern of these species is well defined, yet it is still not very clear which of these environmental factors determine the structure of the assemblies. This paper was developed to evaluate the influence of mean temperature and relative humidity variation in the abundance and richness of blowflies in the Brazilian southernmost state, Rio Grande do Sul, where temperature variation is well marked throughout the year. To evaluate this objective, WOT (Wind Oriented Trap) were installed with beef liver as bait in three environments for 10 consecutive days in each month between July 2003 and June 2004. A total of 13,860 flies were collected distributed among 16 species with a higher frequency of Lucilia eximia (Wiedemann, 1819) and Chrysomya albiceps (Wiedemann, 1819). The mean temperature and relative humidity influence the richness of blowflies, with greater richness and abundance in late spring and early summer, whereas abundance was only influenced by temperature. Each species responded differently with respect to these variables, where L. eximia is not influenced by any of the two abiotic factors, despite the high abundance presented. This paper presents the results of the sensitivity for the presence or absence of species of Calliphoridae and on the variation of the abundance of these species under regime temperature changes and relative humidity with implications for public health and animal management.
\end{abstract}

KEYWORDS. Blow flies, diversity, GLM, models.

RESUMO. A influência da temperatura e umidade na abundância e na riqueza de Calliphoridae (Diptera). As espécies de Calliphoridae são importantes componentes das comunidades de necrófagos na Região Neotropical. Além de estarem envolvidas na degradação da matéria orgânica animal podem também veicular diversos patógenos e parasitos, bem como causar míiases primária e secundária. O padrão de ocorrência destas espécies está bem definido, mas ainda não se tem muito claramente quais fatores ambientais determinam a estrutura destas assembleias. Desenvolvemos este trabalho com o objetivo de avaliar a influência da temperatura média e umidade relativa do ar na variação da abundância e riqueza de espécies de califorídeos no sul do Rio Grande do Sul, onde a variação da temperatura é bem demarcada ao longo do ano. Para avaliar este objetivo, foram instaladas armadilhas WOT (Wind Oriented Trap) com fígado bovino como isca em três ambientes por 10 dias seguidos em cada mês, entre julho de 2003 e junho de 2004. Foram coletados 13.860 dípteros distribuídos entre 16 espécies com maior abundância de Lucilia eximia (Wiedemann, 1819) e Chrysomya albiceps (Wiedemann, 1819). A temperatura média e a umidade relativa influenciaram a variação da riqueza de espécies de califorídeos, com maior riqueza e abundância no final da primavera e inicio do verão, sendo que a abundância foi influenciada apenas pela temperatura. Cada espécie reagiu diferentemente com relação a estas variáveis, com L. eximia não sendo influenciada por nenhuma das duas, apesar da alta abundância apresentada. Este trabalho, apresenta resultados sobre a sensibilidade quanto à presença ou ausência das espécies de califorídeos e sobre a variação da abundância destas espécies sob um regime de alteração da temperatura e umidade relativa do ar com implicações para a saúde pública e manejo animal.

PALAVRAS-CHAVE. Califorídeos, diversidade, GLM, modelos.

In recent years, species distribution models for inference of theoretical and practical questions about climate change and its influence on the probability of occurrence of species have been looked for (LOARIE et al., 2008). In these prediction models, the central problem is to use information about where a species occurs and on the relevant environmental factors. Typically the space variable is not considered and the models are based on two main assumptions: (1) that environmental factors are the main determinants of species distribution and (2) species have reached or almost reached equilibrium in function of these factors (SCHWARTZ et al., 2006). These assumptions behind the species distribution modeling have two analytical approaches, generalized linear models (GLM) and generalized additive models (GAM). The GAM model tends to fit the data better than the GLM model, since it employs additional parameters, but lose simplicity in interpretation, which can be obtained from the GLM model depending on the number of variables used (CHAKRABORTY et al., 2010).

These models have been rarely used in checking the distribution pattern of Calliphoridae species and their abundance as a function of time. Along this axis of analysis it is possible to verify the influence of environmental factors on the occurrence of these species. In general, works on the variation of species richness (S) and abundances of species of Calliphoridae were restricted simply to synanthropy analyzes, based on indexes or ecological correlations, usually pseudo replicated.

The blowfly species are of great importance for human and other animals health. They cause myiasis in humans and other animals, and because of their feeding and oviposition behavior in decomposing organic remains, such as city dumps, carcasses, sewage, feces and rotting fruit, they gain high importance as vectors of pathogens, causing various types of diseases (GUIMARÃES $\&$ PAPAVERO, 1999). This fact is aggravated by their high degree of association with the anthropic environment (Vianna et al., 1998; Souza \& Zuben, 2012). Some species can also be used in criminal investigations, allowing an estimate of postmortem interval (PMI) and the detection of antemortem drugs and toxins (CARVALHO \& LinHARES, 2001; PUJOL-LuZ et al., 2008).

Despite the importance of this group, the knowledge 
of the influence of mean temperature and relative humidity on the occurrence of the blowfly species is incipient, as well as their abundances using robust statistical models that provide for the interaction of these variables. Therefore, the objective of this study was to evaluate the influence of these two abiotic factors on the variation of abundance and species richness of Calliphoridae in southern Rio Grande do Sul.

\section{MATERIAL AND METHODS}

Samples were collected between July 2003 and June 2004 at three sites in the region of Pelotas, state of Rio Grande do Sul, Brazil: Area A (31 ${ }^{\circ} 45^{\prime} 23.51^{\prime \prime} S$, $\left.52^{\circ} 21^{\prime} 45.80^{\prime \prime} \mathrm{W}\right)$, headquarters of the 9th Motorized Infantry Battalion, located in the neighborhood Fragata about $2.5 \mathrm{~km}$ from the center of the city of Pelotas with sparse and introduced vegetation; Area B (31 ${ }^{\circ} 48^{\prime} 14.39^{\prime \prime}$ 'S, $52^{\circ} 24^{\prime} 12.94$ 'W), dam in the Canal São Gonçalo on the municipality of Capão do Leão, located about $13 \mathrm{Km}$ from the center of the city of Pelotas, where cattle is predominant in the margins of the Lagoa do Fragata, where there is a dominance of grasses and vegetation characteristic of wetlands; and Area C (31 $48^{\prime} 55.49^{\prime \prime}$ S, 52 $25^{\circ}$ '53.04'W), Botanical Garden Irmão Luiz Theodoro, municipality of Capão do Leão, located approximately $15.5 \mathrm{~km}$ from the center of the city of Pelotas with vegetation characteristic of Atlantic forest.

We used three WOT (Wind Oriented Trap) traps, a trap for area, containing bovine liver. The traps were prepared according to the model of BROCE et al. (1977) modified by OliveIRA et al. (1982) and used by Vianna et al. $(1998,2004)$ for Calliphoridae and CosTA et al. (2000) for the species of Ophyra Wiedemann, 1830 (Diptera, Muscidae), both in southern Brazil.

The trap was tied on branches of trees to a height of about 1.20 meter from the ground. The installation of the traps occurred on the tenth day of each month and samples were collected in the thirteenth, sixteenth and twentieth day of each month. The trap was removed from the field after 10 days. Within each trap a plastic container with $300 \mathrm{~g}$ liver was placed and remained in the trap for 10 days. Samples were collected in the thirteenth, sixteenth and twentieth day of each month. The samples were taken between 8 and 12 a.m. Each container was covered with tulle to prevent the fall of individuals into the substrate (liver).

Measures of mean temperature and relative humidity were obtained in Estação Agroclimatológica de Pelotas (Capão do Leão), near to the areas.

Data analysis. The influence of mean temperature (MT) and relative humidity (RH) of the sampling period (10 days) in species richness (S), total abundance and abundance of species was evaluated by generalized linear model (GLM) with quasi-Poisson distribution. The similarity between the models constructed for both $\mathrm{S}$ and for abundance was tested by chi-square test $\left(\chi^{2}\right)$ as suggested by CRAWLEY (2007).

The sites were used as replicas for estimates of abundance and $\mathrm{S}$ to avoid spatial and temporal pseudo replication. The tests were performed in the statistical program R (R DeVelopment TeAm, 2011), considering P $<0.05$.

Identification of specimens. The identification of specimens was based on CARVALHO \& Ribeiro (2000). A reference collection was deposited in the Padre Jesus Santiago Moure, Departamento de Zoologia Collection, Universidade Federal do Paraná (UFPR) and another is in the Diptera Collection of the Laboratório de Ecologia de Parasitos e Vetores (LEPAV), Departamento de Microbiologia e Parasitologia, Universidade Federal de Pelotas (UFPel).

\section{RESULTS}

A total of 13,860 flies belonging to 16 species were collected, with Chrysomya albiceps and Lucilia eximia being the most abundant species (Tab. I).

Tab. I. Abundance (Ab) and relative frequency (\%) of blowfly species, captured in WOT trap baited with liver in all three environments of the region of Pelotas and Capão do Leão, RS, from July 2003 to June 2004.

\begin{tabular}{|c|c|c|c|c|c|c|c|c|}
\hline \multirow{3}{*}{\multicolumn{2}{|c|}{ Species }} & \multicolumn{6}{|c|}{ Environments } & \multirow{3}{*}{ Total } \\
\hline & & \multicolumn{2}{|c|}{ A } & \multicolumn{2}{|c|}{$\mathrm{B}$} & \multicolumn{2}{|c|}{$\mathrm{C}$} & \\
\hline & & $\mathrm{Ab}$ & $\%$ & $\mathrm{Ab}$ & $\%$ & $\mathrm{Ab}$ & $\%$ & \\
\hline Calliphora lopesi Mello, 1962 & & 14 & 17 & 49 & 59.8 & 19 & 23.2 & 82 \\
\hline Calliphora vicina Robineau-Desvoidy, 1830 & & 54 & 54 & 0 & 0 & 0 & 0 & 54 \\
\hline Chloroprocta idiodea (Robineau-Desvoidy, 1830) & & 1 & 11.1 & 1 & 11.1 & 7 & 77.8 & 9 \\
\hline Chrysomya albiceps (Wiedemann, 1819) & & 2,486 & 47.6 & 787 & 15.1 & 1,947 & 37.3 & 5,220 \\
\hline Chrysomya megacephala (Fabricius, 1794) & & 208 & 73 & 14 & 4.9 & 63 & 22.1 & 285 \\
\hline Chrysomya putoria (Wiedemann, 1818) & & 19 & 55.9 & 0 & 0 & 15 & 44.1 & 34 \\
\hline Cochliomyia hominivorax (Coquerel, 1858) & & 2 & 18.2 & 3 & 27.3 & 6 & 54.5 & 11 \\
\hline Cochliomyia macellaria (Fabricius, 1775) & & 16 & 20 & 22 & 27.5 & 42 & 52.5 & 80 \\
\hline Hemilucilia segmentaria (Fabricius, 1805) & & 0 & 0 & 2 & 66.7 & 1 & 33.3 & 3 \\
\hline Hemilucilia semidiaphana (Rondani, 1850) & & 37 & 5.5 & 109 & 16.3 & 524 & 78.2 & 670 \\
\hline Hemilucilia souzalopesi Mello, 1972 & & 0 & 0 & 0 & 0 & 13 & 100 & 13 \\
\hline Lucilia cuprina (Wiedemann, 1830) & & 228 & 98.7 & 3 & 1.3 & 0 & 0 & 231 \\
\hline Lucilia eximia (Wiedemann, 1819) & & 2,320 & 36 & 3,255 & 50.6 & 863 & 13.4 & 6,438 \\
\hline Lucilia sericata (Meigen, 1826) & & 4 & 66.6 & 1 & 16.7 & 1 & 16.7 & 6 \\
\hline Paralucilia xanthogeneiates Dear, 1985 & & 27 & 3.8 & 274 & 38.3 & 414 & 57.9 & 715 \\
\hline \multirow[t]{2}{*}{ Sarconesia chlorogaster (Wiedemann, 1830) } & & 2 & 22.2 & 7 & 77.8 & 0 & 0 & 9 \\
\hline & Total & 5,418 & 39.1 & 4,527 & 32.7 & 3,915 & 28.2 & 13,860 \\
\hline
\end{tabular}


The relative humidity $(\mathrm{RH})$ and mean temperature (MT) of the sample period (Tab. II) influenced the variation of $\mathrm{S}$ throughout the year (Fig. $1, \chi^{2}=80.63$, df $=1,35, \mathrm{p}=0.016$ ), while the abundance was influenced only by the mean temperature (Fig. 2, $\chi^{2}=15,758.5$, $\mathrm{df}=1,35, \mathrm{P}=0.002)$ and not by $\mathrm{RH}\left(\chi^{2}=14,905.5, \mathrm{df}=1,35\right.$, $\mathrm{P}=0.5$ ).

Tab. II. Mean temperature $\left({ }^{\circ} \mathrm{C}\right)(\mathrm{MT})$ and relative humidity $(\mathrm{RH})$ of the sampling period in the region of Pelotas and Capão do Leão, RS, Brazil, between July 2003 and June 2004.

\begin{tabular}{lll}
\hline Month & MT & RH \\
\hline July & 12.6 & 85.0 \\
August & 12.3 & 85.7 \\
September & 14.2 & 83.8 \\
October & 18.3 & 79.1 \\
November & 19.9 & 79.0 \\
December & 20.6 & 75.7 \\
January & 23.0 & 82.8 \\
February & 22.5 & 77.2 \\
March & 21.3 & 80.6 \\
April & 20.0 & 83.9 \\
May & 14.7 & 89.5 \\
June & 14.2 & 89.3 \\
\hline
\end{tabular}

Seasonality and monthly frequency of species. According to Figs 3-8, we can identify three groups of species that fit into characteristic patterns of abundance in relation to the months of the year. The first group consisting of $C$. vicina (Fig. 3), H. semidiaphana (Fig. 6), H. souzalopesi (Fig. 6), L. cuprina (Fig. 7), L. eximia (Fig. 7), C. idiodea (Fig. 8), P. xanthogeniates (Fig. 8) and $S$. chlorogaster (Fig. 8) occur in high abundance between October and December. The other group consists of the species C. albiceps (Fig. 4), C. megacephala (Fig. 4), C. putoria (Fig. 4), C. hominivorax (Fig. 5) and $C$. macellaria (Fig. 5) which occur in high abundance between December and March, with a peak of population in late summer in the southern hemisphere. The third group consists of species that was not possible to adjust

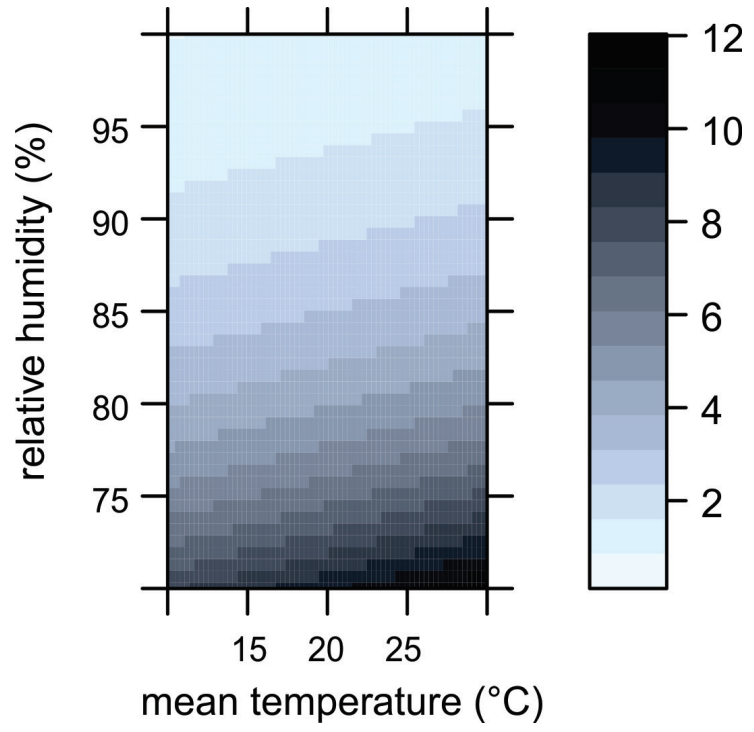

Fig. 1. Species richness (right bar) of Calliphoridae as function of mean temperature $\left({ }^{\circ} \mathrm{C}\right)$ and relative humidity $(\%)$ in the region of Pelotas and Capão do Leão, state of Rio Grande do Sul, Brazil, between July 2003 and June 2004. Species richness estimated (SEST) corresponds to the maximum value (darker area in the graph) and minimum (lighter area in the graph) obtained through generalized linear model (GLM) with quasi-Poisson distribution.

to the other two groups, such as C. lopesi (Fig. 3), $H$. segmentaria (Fig. 6) and L. sericata (Fig. 7).

The evaluation of the influence of MT and the $\mathrm{RH}$ and the interaction of these two variables using the GLM model in the abundance of species of Calliphoridae revealed five patterns with respect to the statistical models considered (Tab. III): i) without influence of any of the variables; ii) with influence of $\mathrm{RH}$ and the interaction between this variable and MT, with no influence of isolated MT; iii) influence of only the MT; iv) influence of only the RH and v) influence of only the MT and RH with no interaction between the two variables. In seven species was not possible to establish a robust model because of low abundance ( $<50$ flies) (see Tab. I).

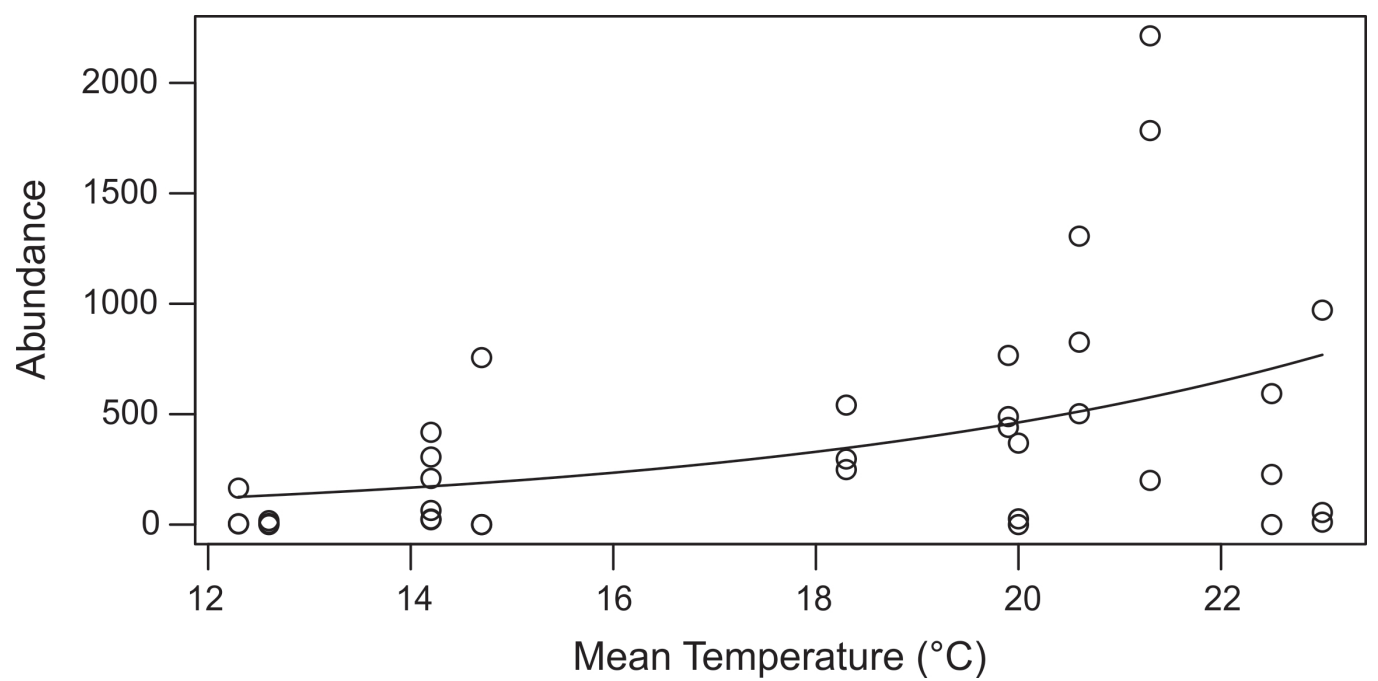

Fig. 2. Abundance of Calliphoridae as a function of mean temperature $\left({ }^{\circ} \mathrm{C}\right)$ in the region of Pelotas and Capão do Leão, RS, Brazil between July 2003 and June 2004. The curve corresponds to the generalized linear model (GLM) with quasi-Poisson distribution. 


\section{Calliphora lopesi}

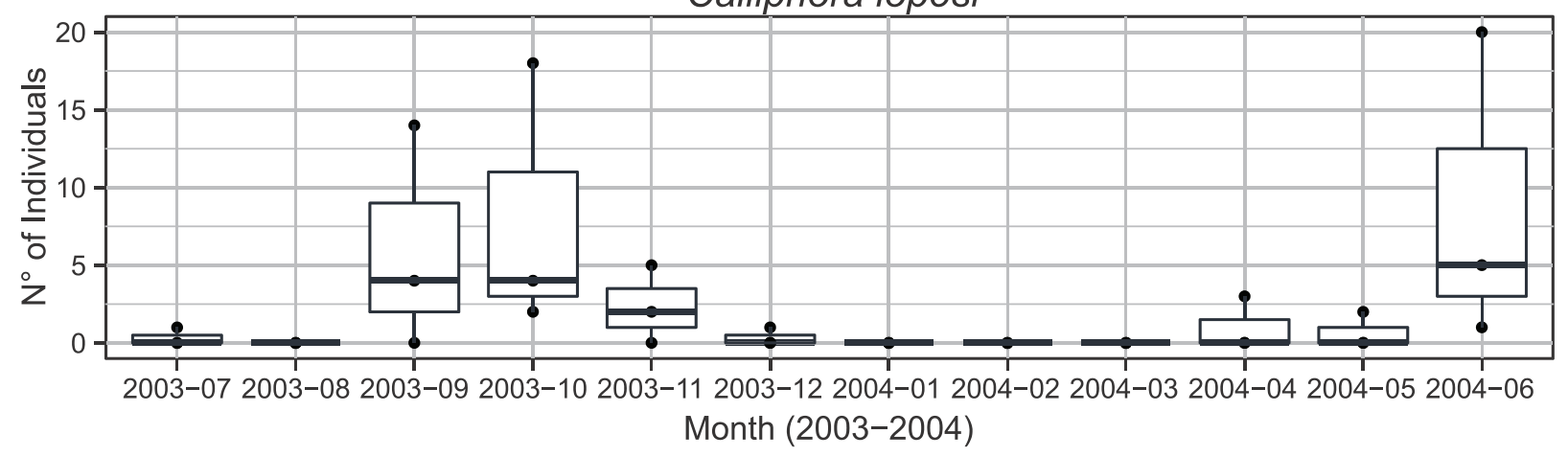

Calliphora vicina

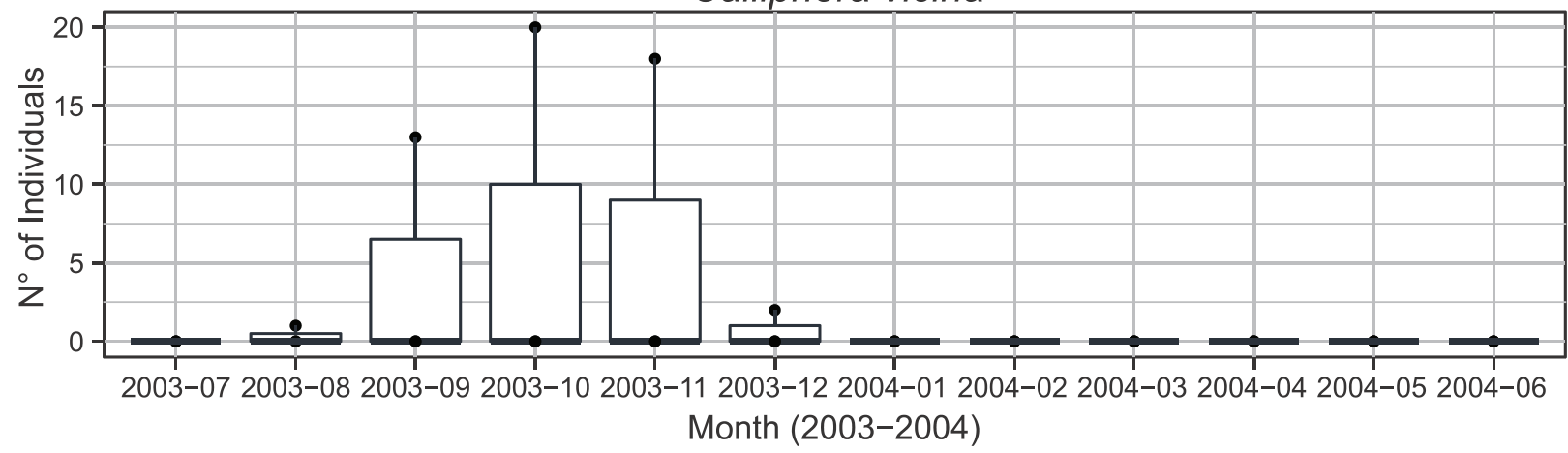

Fig 3. Mean (transverse dark bar), error (box) and standard deviation of the abundance Calliphora species between July 2003 and June 2004 in Pelotas, RS, Brazil.
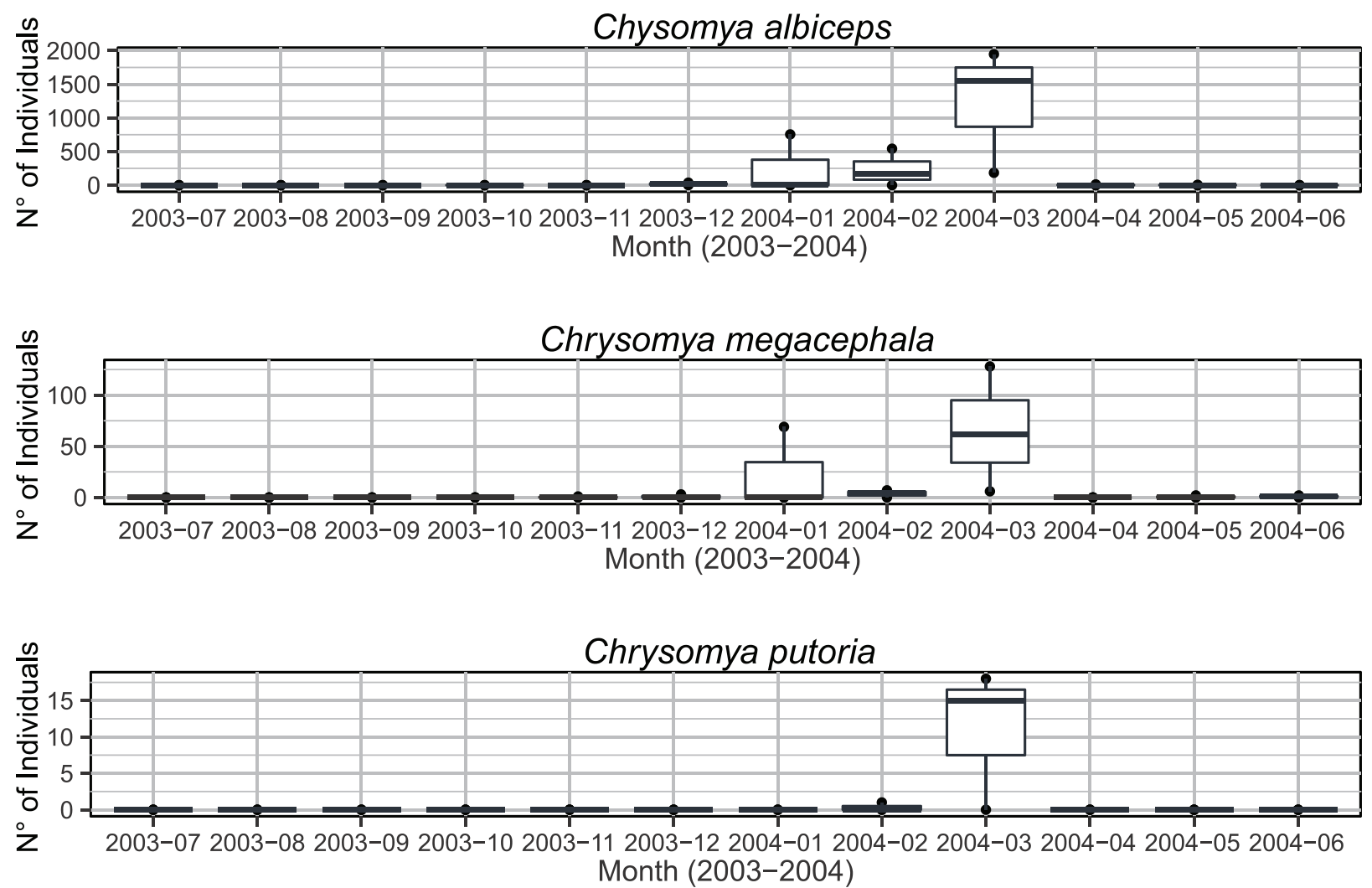

Fig 4. Mean (transverse dark bar), error (box) and standard deviation of the abundance Chrysomya species between July 2003 and June 2004 in Pelotas, RS, Brazil. 


\section{Cochliomyia hominivorax}

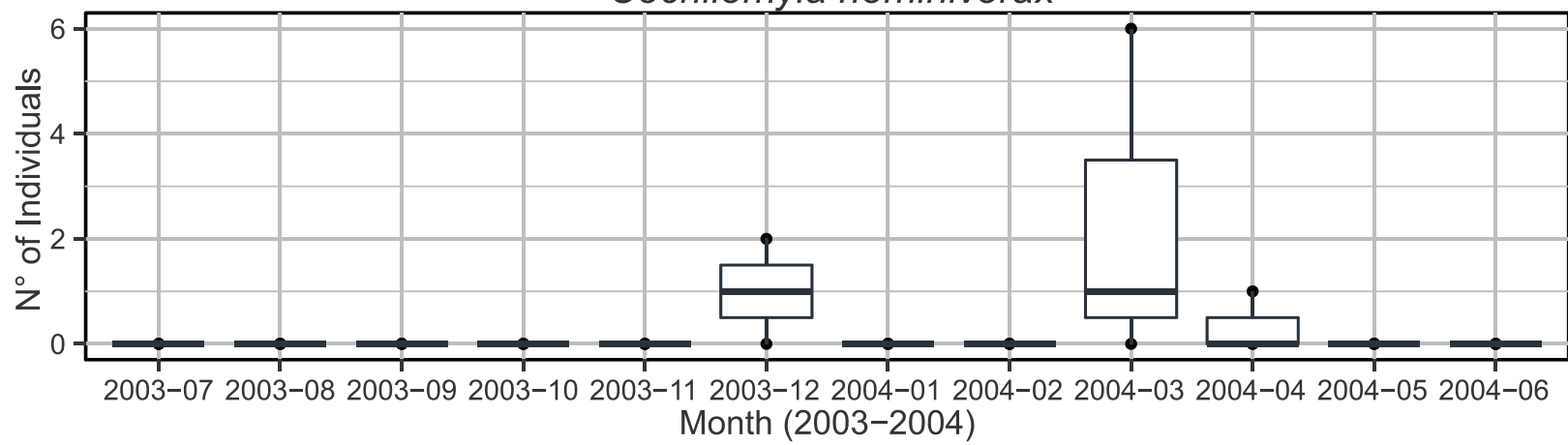

Cochliomyia macellaria

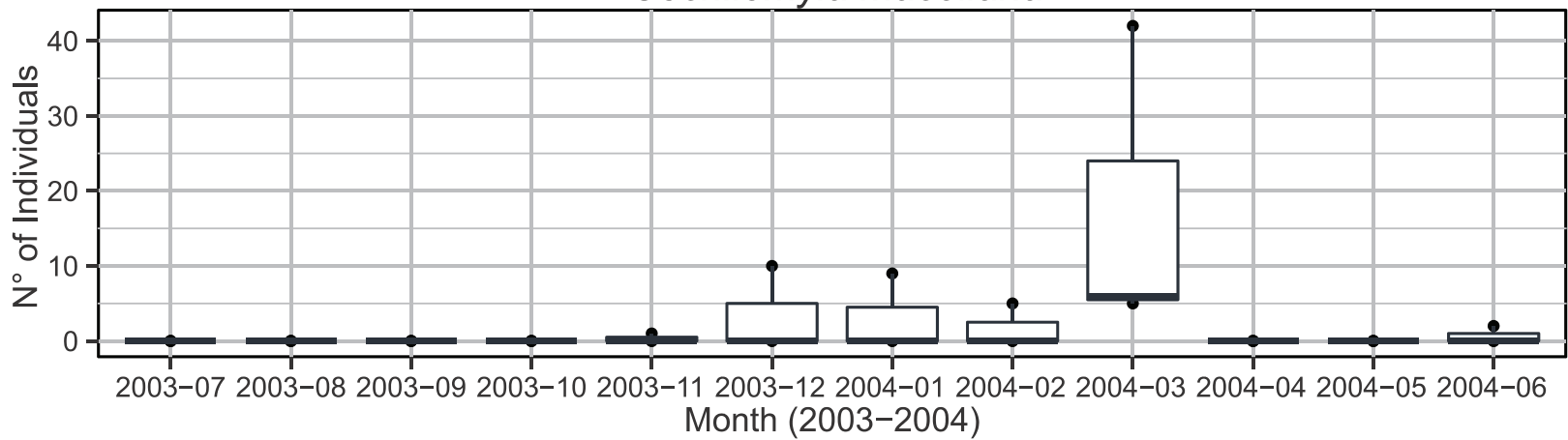

Fig 5. Mean (transverse dark bar), error (box) and standard deviation of the abundance Cochliomyia species between July 2003 and June 2004 in Pelotas, RS, Brazil.
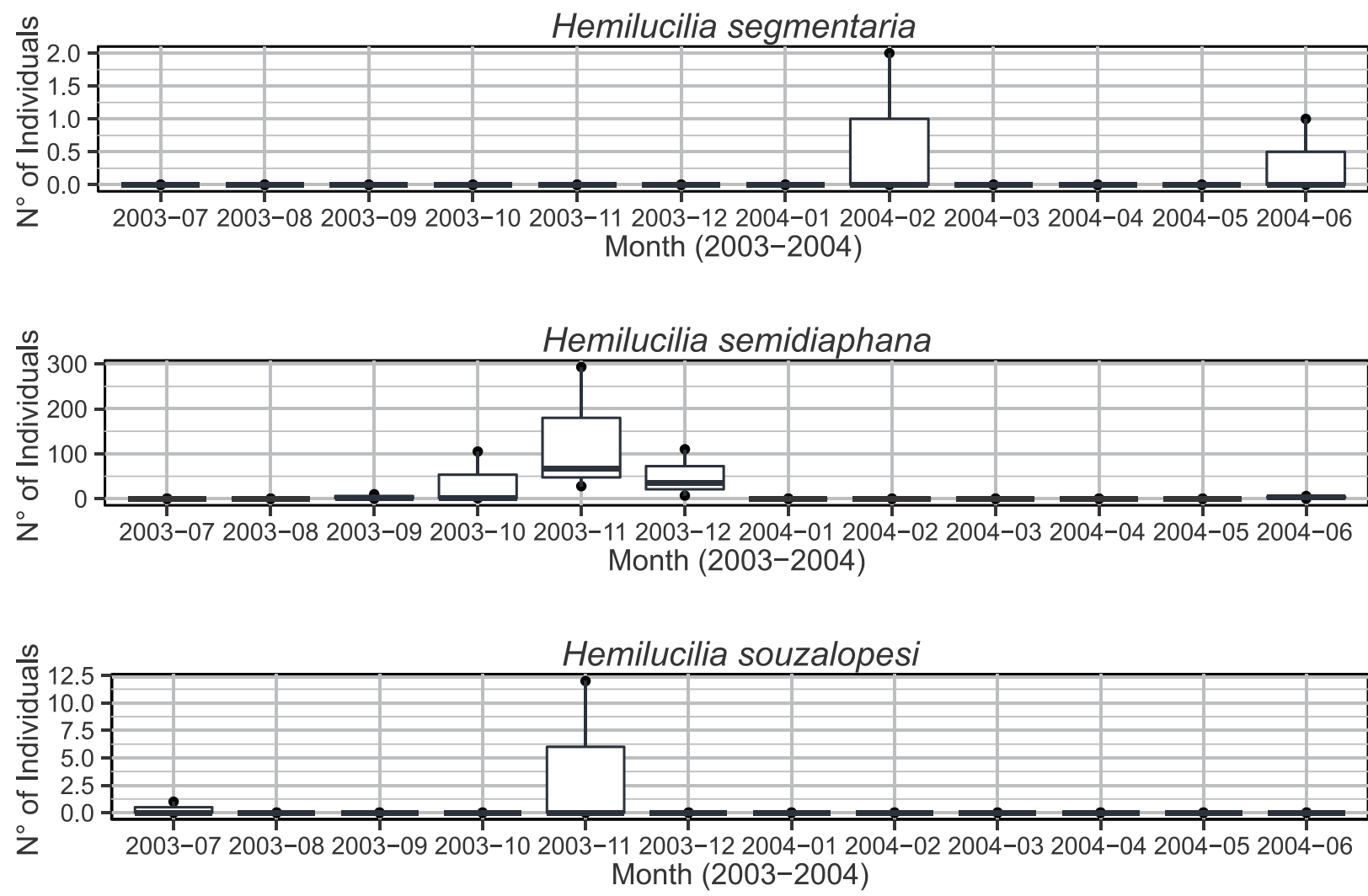

Fig 6. Mean (transverse dark bar), error (box) and standard deviation of the abundance Hemilucilia species between July 2003 and June 2004 in Pelotas, RS, Brazil. 

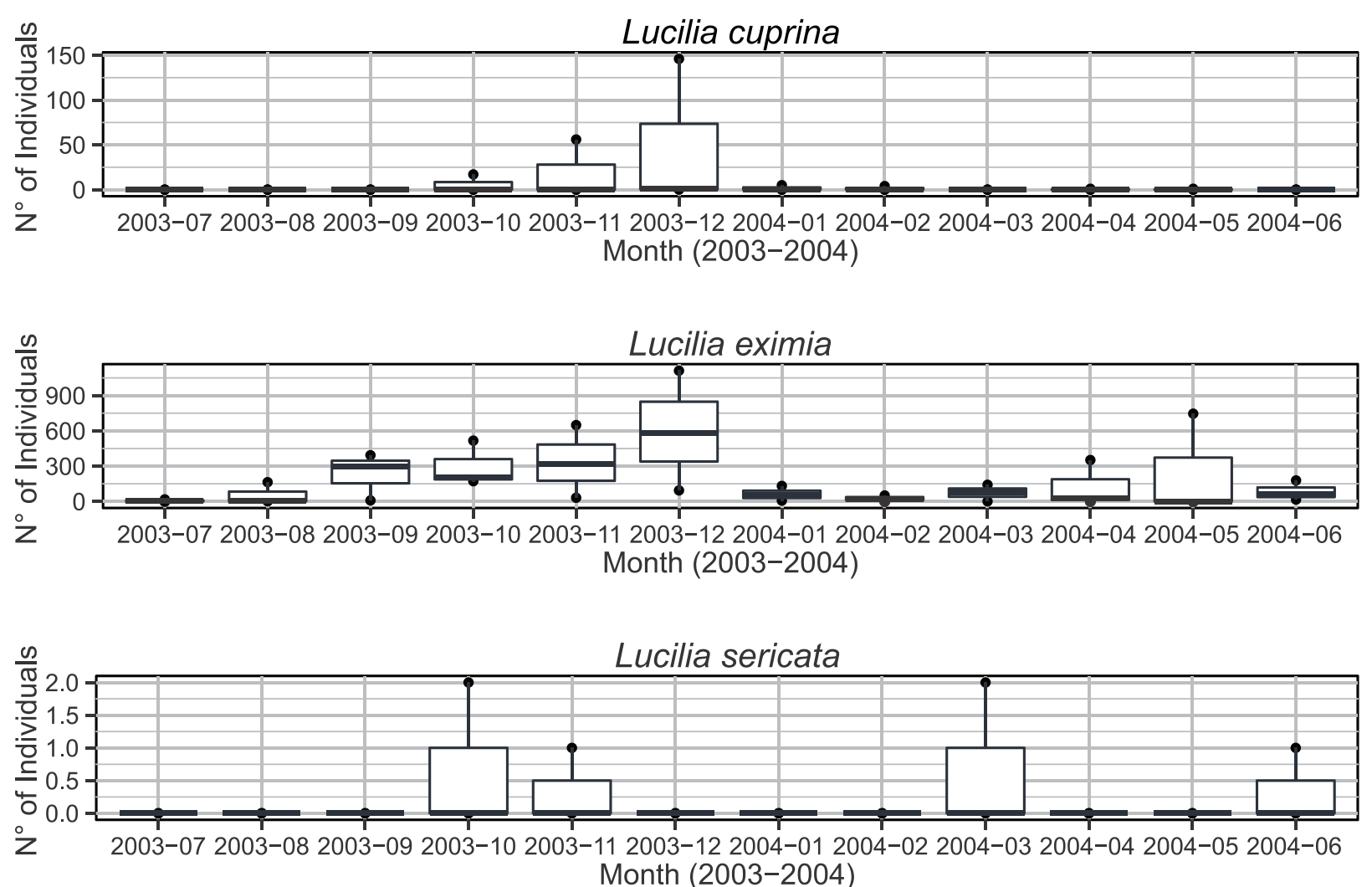

Fig 7. Mean (transverse dark bar), error (box) and standard deviation of the abundance Lucilia species between July 2003 and June 2004 in Pelotas, RS, Brazil.
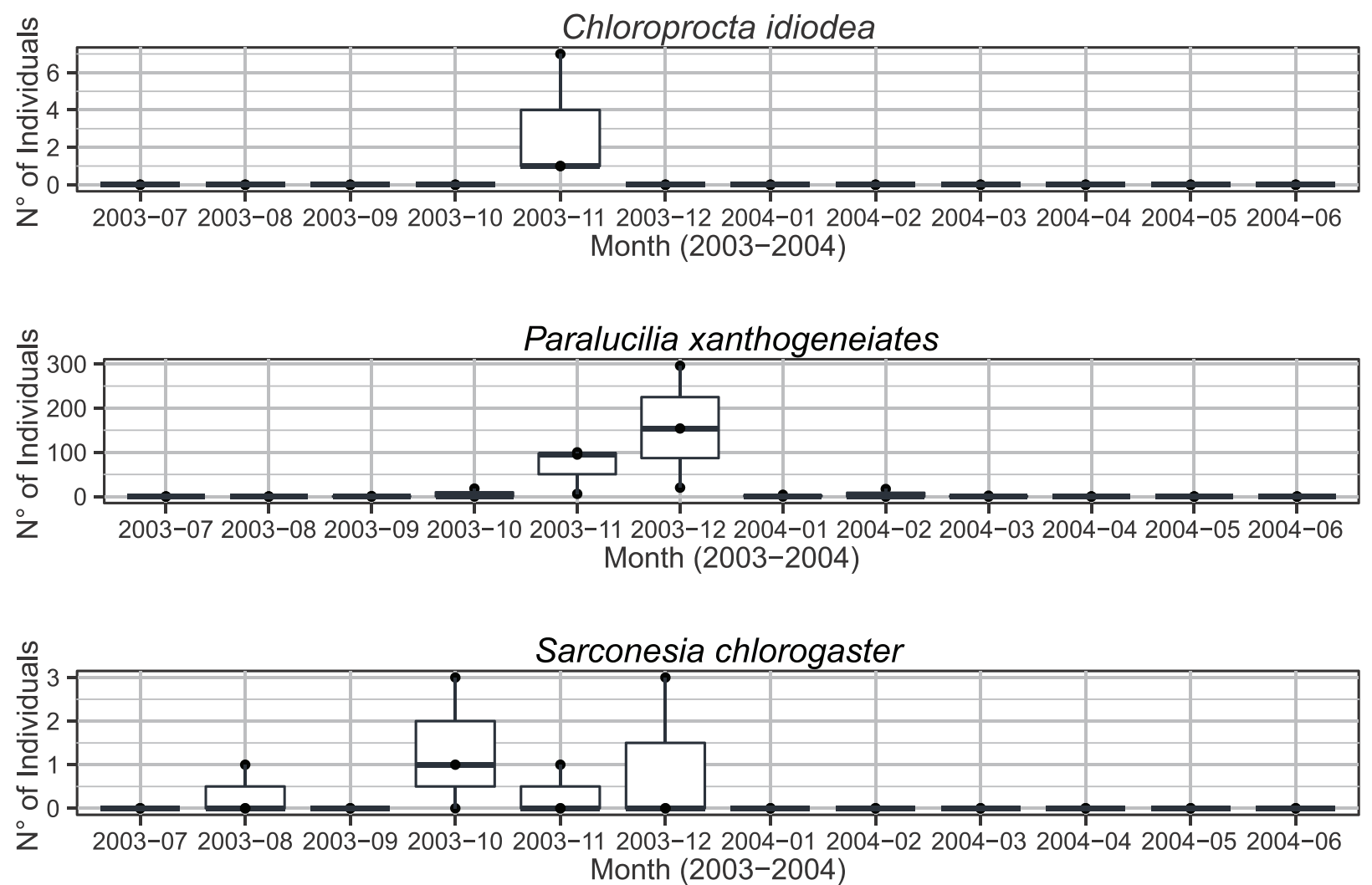

Fig 8. Mean (transverse dark bar), error (box) and standard deviation of the abundance Chloroprocta idiodea, Paralucilia xanthogeneiates and Sarconesia chlorogaster species between July 2003 and June 2004 in Pelotas, RS, Brazil. 
Tab. III. Influence of mean temperature (MT), relative air humidity (RH) and the interaction of these two factors (mt*rh) variation in the abundance of species of Calliphoridae in southern Rio Grande do Sul, Brazil, using generalized linear models (GLM) with quasi-Poisson distribution considering 35 degrees of freedom in each test. The models built with the variables MT and RH were compared by chi-square $\left(\chi^{2}\right)$ at $5 \%$ probability.

\begin{tabular}{|c|c|c|c|c|c|c|c|}
\hline Species & $\mathrm{Mt}$ & $\mathrm{Rh}$ & $\mathrm{mt} * \mathrm{rh}$ & Model & $\chi^{2}$ & $\mathrm{P}$ & Distribution \\
\hline Calliphora lopesi & no & no & no & no & 20.74 & 0.558 & quasi-Poisson \\
\hline Calliphora vicina & no & yes & yes & $y=e^{275.31-12.82^{*} m t-3.23^{*} r h+0.15^{*} m t^{*} r h}$ & 249.55 & 0.003 & quasi-Poisson \\
\hline Chrysomya albiceps & yes & no & no & $y=e^{-5.23+0.50^{*} m t}$ & $13,813.00$ & 0.013 & quasi-Poisson \\
\hline Chrysomya megacephala & yes & no & no & $\mathrm{y}=e^{-7.61+0.48^{*} m t}$ & 817.34 & 0.022 & quasi-Poisson \\
\hline Cochliomyia macellaria & no & no & no & no & 328.27 & 0.123 & quasi-Poisson \\
\hline Hemilucilia semidiaphana & no & yes & no & $y=e^{26.39-0.29 *^{*} \mathrm{rh}}$ & $2,532.50$ & 0.025 & quasi-Poisson \\
\hline Lucilia cuprina & no & no & no & no & $1,117.76$ & 0.981 & quasi-Poisson \\
\hline Lucilia eximia & no & no & no & no & $10,697.50$ & 0.326 & quasi-Poisson \\
\hline Paralucilia xanthogeniates & yes & yes & no & $y=e^{64.58-0.27 * \mathrm{mt}-0.71^{*} \mathrm{rh}}$ & $2,787.99$ & $<0.001$ & quasi-Poisson \\
\hline
\end{tabular}

\section{DISCUSSION}

A significant shift in the blowfly faunal structure was observed in the field experiment between seasons. The spring fauna persist up until the decrease of $\mathrm{RH}$ on late summer, in march-april. In the late summer the richness decreased dramatically on all localities. The relative dominance of different genera also changed considerably. Subsequently, a new fauna emerged with Chrysomya and Cochliomyia species.

The pattern of seasonality of $L$. eximia and $C$. albiceps observed in this study is in accordance with other studies in the same region (VIANNA et al., 1998, 2004; SouZA et al., 2008; KRÜGER et al., 2010). There was a numerical dominance of L. eximia in winter, spring and autumn while $C$. albiceps was numerically dominant in summer at all sites, with a marked decrease in the frequency of occurrence of $L$. eximia in this season. MoretTI et al. (2008) and KRÜGER et al. (2010) attributed this pattern to three possibilities: i) the type and size of substrates in each season; ii) optimum conditions for the development and iii) the capacity of predation of $C$. albiceps. The short interval between generations at high temperatures (QUEIROZ \& MILWARDDE-AzeVedo, 1991; KRÜGER et al., 2010) and the high predation capacity of $C$. albiceps are factors that can be affect the abundance of other Calliphoridae that colonizes ephemeral resources, such as L. eximia during the southern hemisphere summer. Models to check the influence of randomness on population fluctuations of $C$. albiceps and L. eximia, based on data of South American populations have shown that intrinsic factors such as predation are more important than the extrinsic (environmental factors) to explain the variation in the abundance of these two species (Godor et al., 2001; Silva et al., 2003; Gĩ̃o \& Godoy, 2006). This observation supports the third explanation of MoRETTI et al. (2008) and KRÜGER et al. (2010) aforementioned and is supported by the observed data in southern Brazil to explain the antagonistic fluctuation of $C$. albiceps and L. eximia. Only the abundance of $C$. albiceps responds positively to increased temperature, whereas the abundance of $L$. eximia is not explained by abiotic factors, probably due to the influence of the occurrence in high abundance of $C$. albiceps.
Density-independent factors such as MT and RH are important in determining the richness (Fig. 1) and MT in determining abundance (Fig. 2) of blowflies in southern Brazil and other regions of South America, as in the province of Buenos Aires in Argentina (CENTENo et al., 2002), São Paulo (CARVAlho \& Linhares, 2001; CARvalho et al., 2004) and in the cerrado of Minas Gerais (RosA et al., 2009, 2011), although the tests used are very different from the GLM models used in this study. The seasonality influenced the establishment of blowfly species through the MT and RH, and these two variables influenced the population fluctuation of each species differently, except the abundance of $L$. eximia, C. lopesi, C. macellaria, and L. cuprina.

With the eminent climate changes, increased warming and decreased humidity, there is a strong tendency for carrion flies communities to be impacted as shown by the analyses performed in the present study. The increase in temperature and reduction of relative humidity interactions are very important in determining the occurrence of most species of this family in an area, considering the intervals of data interpolation shown in this study. But not all species respond similarly because they have a single set of reactions, or because they suffer from the influence of biotic factors more strongly than other species (ANGILLETTA, 2009).

The genera Chrysomya and Cochliomyia have strong tendency to increase abundance with increasing temperature without suffering influences of the variation of relative humidity, considering specially the data for C. albiceps and $C$. hominvorax, two species that are important to forensic entomology and animal health (Guimarães \& PAPAVEro, 1999; Pujol-Luz et al., 2008). The first species is a facultative predator (FARIA et $a l ., 1999)$ and the second is a biontophagous that causes screwworm (ZUMPT, 1965), both in the larval stage. Therefore, the temperature increase with a decrease in $\mathrm{RH}$ would facilitate the early peak occurrence of these species when compared to that observed in this work and others (WIEGAND et al., 1991; VIANNA et al., 2004). In this case, we would have an increase in populations of Chrysomya and the frequency of screwworms before summer. According to the results obtained by the application of statistical models, other species such as C. vicina and $P$. xanthogeniates would also be heavily 
impacted by the increase in MT and the presence of a predator in decomposing animal organic matter, with the possibility of displacement of these species from these regions to others with lower temperatures.

From the results presented it is concluded that temperature and humidity are among the main regulating factors of the blowfly fauna in wetlands of southern Brazil. Generally, temperature is a more important factor than humidity, but for the richness and the frequency of occurrence of some species, the state of humidity is a major factor to interact with temperature to determine the occurrence of a high richness through robust statistical models. From the significant changes of the blowfly fauna detected in this study, it is proposed that the envisaged global and regional changes of temperature and humidity in the future will cause serious alterations in the blowfly fauna. Importantly, it has been shown that the response of blowflies to climate change is very rapid. Therefore, this fly group represents an especially useful tool in modeling the impact, and monitoring the biological effects of global climate change.

Acknowledgements. We are grateful to M.Sc. Juliano Lessa Pinto Duarte (UFPEL) and Dr. Thiago de Carvalho Moretti (USP) for critically reading the paper.

\section{REFERENCES}

Angilletta, M. J. 2009. Thermal Adaptation: A Theoretical and Empirical Synthesis. New York, Oxford University Press. 291p.

Broce, A. B.; Goodenowgh, J. L. \& Coppedge, J. R. 1977. A wind oriented trap for screwworm flies. Journal of Economic Entomology 70(4):413-416.

Carvalho, C. J. B. de \& Ribeiro, P. B. 2000. Chave de identificação das espécies de Calliphoridae (Diptera) do Sul do Brasil. Revista Brasileira de Parasitologia Veterinária 9:169-173.

Carvalho, L. M. L. \& Linhares, A. X. 2001. Seasonality of insect succession and pig carcass decomposition in a natural forest area in Southeastern Brazil. Journal Forensic Science 46:604-608.

Carvalho, L. M. L; Thyssen, P. J.; Goff, M. L. \& Linhares, A. X. 2004. Observations on succession patterns of necrophagous insects on pig carcass in a urban area of Southeastern Brazil. Aggrawal's Internet Journal of Forensic Medicine and Toxicology 5:40-44

Centeno, N.; Maldonado, M. \& Oliva, A. 2002. Seasonal patterns of arthropods occurring on sheltered and unsheltered pig carcasses in Buenos Aires Province (Argentina). Forensic Science International 126:63-70

Chakraborty, A.; Gelfand, A. E.; Wilson, A. M.; Latimer, A. M. \& SILANDER-JR, J. A. 2010. Modeling large scale species abundance with latent spatial processes. The Annals of Applied Statistics 4(3):1403-1429.

Costa, P. R. P.; Franz, R. L. \& Ribeiro, P. B. 2000. Synanthropy of Ophyra spp. (Diptera, Muscidae) in Pelotas, RS, Brazil. Revista Brasileira de Parasitologia Veterinária 9:165-168.

Crawley, M. J. 2007. The R Book. Chichester, John Wiley \& Sons. 942p.

Faria, L. D. B.; Orsi, L.; Trinca, L. A. \& Godoy, W. A. C. 1999. Larval predation by Chrysomya albiceps on Cochliomyia macellaria, Chrysomya megacephala and Chrysomya putoria. Entomologia Experimentalis et Applicata 90:149-155.

Gião, J. Z. \& GodoY, W. A. C. 2006. Seasonal population dynamics in Lucilia eximia (Wiedemann) (Diptera, Calliphoridae). Neotropical Entomology 35:753-756.
Godoy, W. A. C.; Zuben, F. J. V.; Zuben, C. J. V. \& Reis, S. F. 2001. Spatiotemporal dynamics and transition from asymptotic equilibrium to bounded oscillations in Chrysomya albiceps (Diptera. Calliphoridae). Memórias do Instituto Oswaldo Cruz 96:627-634

Guimarães, J. H. \& PAPAVERo, N. 1999. Myiasis in man and animals in the neotropical region: bibliographic database. São Paulo, Editora Plêide/FAPESP. 308p.

Krüger, R. F.; Kirst, F. D. \& Souza, A. S. B. 2010. Rate of development of forensically-important Diptera in southern Brazil. Revista Brasileira de Entomologia 54:624-629.

Loarie, S. R.; Carter, B. E.; Hayhoe, K.; McMahon, S.; Moe, R.; KNight, C. A. \& ACKerly, D. D. 2008. Climate change and the future of California's endemic flora. PLoS ONE 3:2502

Moretti, T. D. C; Ribeiro, O. B.; Thyssen, P. J. \& Solis, D. R. 2008 Insects on decomposing carcasses of small rodents in a secondary forest in Southeastern Brazil. European Journal of Entomology 105:691-696.

Oliveira, C. M. B.; Moya-Borja, G. E. \& Mello, R. P. 1982. Flutuação populacional de Cochliomyia hominivorax no município de Itaguaí, Rio de Janeiro. Pesquisa Agropecuária Brasileira 2:139-142.

Pujol-Luz, J. R.; Arantes, L. C. \& Constantino, R. 2008. Cem anos da entomologia Forense no Brasil (1908 - 2008). Revista Brasileira de Entomologia 52:485-492.

Queiroz, M. M. C. \& Milward-De-Azevedo, E. M. V. 1991 Técnicas de criação e alguns aspectos da biologia de Chrysomya albiceps (Wiedemann) (Diptera, Calliphoridae) em condições de laboratório. Revista Brasileira de Zoologia 8:75-84.

R Development Core Team. 2011. R: A Language and environment for statistical computing. Vienna, R Foundation for Statistical Computing. Available at $<$ http://www.R-project.org $>$. Accessed on December, 2011.

Rosa, T. A.; Babata, M. L. Y.; Souza, C. M.; Sousa, D.; Mello-Patiu, C. A. \& Mendes, J. 2009. Dípteros de Interesse Forense em Dois Perfis de Vegetação de Cerrado em Uberlândia. MG. Neotropical Entomology 38:859-866.

Rosa, T. A.; Babata, M. L. Y.; Souza, C. M.; Sousa, D.; MelloPatiu, C. A.; VaZ-De-Mello, F. \& Mendes, J. 2011. Arthropods associated with pig carrion in two vegetation profiles of Cerrado in the State of Minas Gerais. Brazil. Revista Brasileira de Entomologia 55:424-434.

Schwartz, M. W.; Iverson, L. R.; Prasad, A. M.; Matthews, S. N. \& O'Connor, R. J. 2006. Predicting extinctions as a result of climate change. Ecology 87:1611-1615.

Silva, I. C. R.; Mancera, P. F. A. \& Godoy, W. A. C. 2003. Population dynamics of Lucilia eximia (Diptera. Calliphoridae). Journal of Applied Entomology 127:2-6

SouZA, A. S. B.; KIRST, F. D. \& KRÜGER, R. F. 2008. Insects of forensic importance from Rio Grande do Sul state in Southern Brazil. Revista Brasileira de Entomologia 52:641-646.

Souza, C. R. \& Zuben, C. J. V. 2012. Diversity and synanthropy of Calliphoridae (Diptera) in the region of Rio Claro, SP, Brazil. Neotropical Entomology 41:243-248.

Vianna, E. E. S.; Brum, J. G. W.; Ribeiro, P. B.; Berne, M. E. A. \& SilveIRA-JR, P. 1998. Sinanthropy of Calliphoridae (Diptera) in Pelotas, Rio Grande do Sul State, Brazil. Revista Brasileira de Parasitologia Veterinária 7:141-147.

Vianna, E. E. S.; Costa P. R. P.; Fernandes A. L. \& Ribeiro, P. B. 2004. Abundância e flutuação populacional das espécies de Chrysomya (Diptera, Calliphoridae) em Pelotas, Rio Grande do Sul, Brasil. Iheringia, Série Zoologia 94(3):231-234

Wiegand, M. M.; Brum, J. G. W.; Ribeiro, P. B. \& Costa, P. R. P. 1991. Flutuação populacional de Cochliomyia hominivorax e C. macellaria (Diptera: Calliphoridae) no Município do Capão do Leão, Rio Grande do Sul. Arquivo Brasileiro de Medicina Veterinária e Zootecnia 42:155-162.

ZuMPT, F. 1965. Myiasis in man and animals in the Old World London, Butterworhs. 267p. 